\title{
Partisipasi Masyarakat Dalam Penyusunan Musrenbang Di Desa Sipodeceng Kecamatan Baranti
}

\author{
Rahayu Arsyad \\ Npm: 43182044 \\ Email Ayhuabong@ gmail.com \\ Universitas Muhammadiyah Sidenreng Rappang
}

\begin{abstract}
Abstrak
Penelitian ini dilakukan untuk mengetahui bagaimana partisipasi masyarakat di desa Sipodeceng dalam penyusunan musrembang. Penelitian ini dilakukan dengan metode studi literature. Di desa sipodeceng memiliki populasi 30785 jiwa penduduk, dengan teknik pengumpulan data yaitu probability sampling. Dengan penelitian ini dapat menjadi acuan dalam mengambil tindakan. Hasil penelitian ini menunjukkan partisipasi masyarakat sudah baik dalam perlibatan penyusunan musrembang di desa Baranti
\end{abstract}

Keywords: Partisipasi masyarakat, musrembang

A. Pendahuluan

Partisipasi dimaknai yaitu "partisipasi masyarakat adalah keikutsertaan masyarakat untuk mengakomodasikan kepentingan mereka dalam proses penyusunan rencana pembangunan" Dari pengertian di atas dapat disimpulkan bahwa partisipasi masyarakat merupakan keterlibatan atau keikutsertaan seseorang masyarakat dalam proses interaksi sosial, pengidentifikasian masalah dan potensi yang ada di masyarakat dalam situasi tertentu, baik dalam pengambilan keputusan (solusi) menangani masalah, pelaksanaan upaya mengatasi masalah, dan proses keterlibatan 
masyarakat di dalam mengevaluasi perubahan yang terjadi. Dari definisi ini penulis melihat bahwa keterlibatan partisipasi masyarakat yang rendah di Kelurahan Kanyuara dapat mengakibatkan perencanaan pembangunan melalui musrenbang tidak dapat mencapai hasil yang maksimal.(ahmad mustanir, 2017)

Melalui pembangunan yang berbasis partisipasi masyarakat ini akan dapat dilaksanakan pembangunan daerah yang benar-benar sesuai dengan kebutuhan dan aspirasi masyarakat. Mekanisme perencanaan tersebut dimulai dari kegiatan Musyawarah Perencanaan Pembangunan tingkat desa/kelurahan, tingkat kecamatan, tingkat kabupaten, yang selanjutnya di tingkat regional dan nasional. (Mustanir et al., 2018) Namun pada hakikatnya pelaksanaan Musyawarah Perencanaan Pembangunan desa/kelurahan hanya melibatkan pemangku kepentingan, sehingga tidak terlihat lagi keterlibatan masyarakat.

keterlibatan masyarakat dalam pemeliharaan pembangunan yang dihasilkan terkadang masyarakat belum berpartisipasi dengan baik untuk memelihara pembangunan tersebut.padahal partisipasi masyarakat tidak hanya diperlukan pada saat pelaksanaan tapi juga mulai tahapan perencanaan bahkan pengambilan keputusan. Pelaksanaan Musrenbang yang berjenjang mulai dari tingkat desa/kelurahan, kecamatan, kabupaten/kota, propinsi, hingga dibawa ke tingkat nasional merupakan kesempatan emas bagi masyarakat untuk dapat terlibat perencanaan pembangunan. dalam proses perencanaan pembangunan serta menganalisis bagaimana akan dilakukan secara mendalam sebagai upaya pemerintah untuk meningkatkan partisipasi masyarakat dalam proses perencanaan pembangunan.

Berdasarkan uraian di atas maka peneliti mengangkat beberapa masalah sesuai dengan judul "Partisipasi masyarakat dalam penyusunan musrenbang di Desa Sipodeceng” yaitu :

1. Bagaimana partisipasi masyarakat dalam musrenbang?

2. Faktor faktor apakah yang mempengaruhi partisipasi masyarakat? 
B. Tinjauan pustaka

1. Partisipasi masyarakat

Dalam jurnal (Mustanir \& Razak, 2017) Undang-Undang No. 25 Tahun 2004 Sistem Perencanaan Pembangunan Nasional mengartikan "partisipasi masyarakat adalah keikutsertaan masyarakat untuk mengakomodasikan kepentingan mereka dalam proses penyusunan rencana pembangunan”. Dari pengertian di atas menurut Isbandi dalam

Ahmad Mustanir (2017: 356) bahwa partisipasi masyarakat merupakan keterlibatan atau keikutsertaan seseorang masyarakat dalam proses interaksi sosial, pengidentifikasian masalah dan potensi yang ada di masyarakat dalam situasi tertentu, baik dalam pengambilan keputusan (solusi) menangani masalah, pelaksanaan upaya mengatasi masalah, dan proses keterlibatan masyarakat di dalam mengevaluasi perubahan yang terjadi. Menurut [1], Partisipasi anggota masyarakat adalah keterlibatan anggota masyarakat dalam pembangunan, meliputi kegiatan dalam perencanaan dan pelaksanaan (implementasi) program/proyek pembangunan yang dikerjakan di dalam masyarakat. Pengertian partisipasi masyarakat, [8], [10] mengemukakan tentang lingkup partisipasi dengan bertolak pada urutan proses perencanaan pembangunan, maka secara rinci jenis partisipasi masyarakat dalam pembangunan sebagai berikut:

1) Partisipasi dalam pengambilan keputusan,

2) Partisipasi dalam pelaksanaan kegiatan,

3) Partisipasi dalam pemantauan dan evaluasi pembangunan,

4) Partisipasi dalam pemanfaatan hasil-hasil pembangunan

Menurut Isbandi dalam (Mustanir et al., 2020) bahwa partisipasi masyarakat merupakan keterlibatan atau keikutsertaan seseorang masyarakat dalam proses interaksi sosial, pengidentifikasian masalah dan potensi yang ada di masyarakat dalam situasi tertentu, baik dalam pengambilan keputusan (solusi) menangani masalah, pelaksanaan upaya 
mengatasi masalah, dan proses keterlibatan masyarakat di dalam mengevaluasi perubahan yang terjadi . Partisipasi adalah keikutsertaan seseorang atau sekelompok anggota masyarakat dalam suatu kegiatan (Mardikanto \& Poerwoko, 2015). Sedangkan Verhangen dalam (Mardikanto \& Poerwoko, 2015) (Irwan et al. 2019) menyatakan bahwa partisipasi merupakan suatu bentuk khusus dari interaksi dan komunikasi yang berkaitan dengan pembangian kewenangan, tanggung jawab, dan manfaat. Menurut Sumarto dalam (Fadil, 2013) bahwa partisipasi merupakan suatu

proses yang memungkinkan adanya interaksi yang lebih baik antar stakeholders sehingga kesepakatan-kesepakatan dan tindakan yang bersifat inovatif lebih mungkin tercipta dalam proses deliberatif, dimana ruang untuk mendengarkan, belajar, refleksi dan memulai suatu aksi bersama terjadi.

Daniels dan Walker (2005): Masyarakat harus memiliki suara dalam keputusan tentang tindakan yang mempengaruhi kehidupan mereka. Survei partisipasi oleh The International Association of Publik Participation telah mengidentifikasi nilai inti partisipasi sebagai berikut: a. Partisipasi masyarakat meliputi jaminan bahwa kontribusi masyarakat akan mempengaruhi keputusan

b. Proses partisipasi masyarakat mengkomunikasikan dan memenuhi kebutuhan proses semua partisipan

c. Proses partiipasi masyarakat berupaya dan memfasilitasi keterlibatan mereka yang berpotensi untuk terpengaruh

d. Proses partisipasi masyarakat melibatkan partisipan dalam mendefinisikan bagaimana mereka berpartisipasi

e. Proses partisipasi masyarakat mengkomunikasikan kepada partisipan bagaimana input mereka digunakan atau tidak digunakan

f. Proses partisipasi masyarakat memberi partisipan informasi yang mereka butuhkan dengan cara bermakna.

Indikator 
perencanaan pembangunan (Imron, Ali. 2008). Dalam jurnal (Ahmad Mustanir1) et al., 2019) Perencanaan yang menghasilkan program pembangunan yang diharapkan dapat memberikan dampak terhadap peningkatan kesejahteraan, kemakmuran dan perdamaian masyarakat dalam jangka panjang.

(Mustanir \& Yasin, 2018) Salah satu kegiatan perencanaan pembangunan yang biasanya dilaksanakan adalah musyawarah perencanaan pembangunan yaitu forum-forum multi-pihak terbuka yang secara bersama mengidentifikasi dan menentukan prioritas kebijakan pembangunan masyarakat. (Tim Kerja Buku Panduan Penyelenggaraan Musrenbang, 2008 :3). Musyawarah perencanaan pembangunan merupakan forum perencanaan (program) yang diselenggarakan oleh lembaga publik yaitu pemerintah desa bekerjasama dengan warga dan para pemangku kepentingan lainnya. Musyawarah perencanaan pembangunan yang menurut Sumpeno (2008:28) merupakan perencanaan pembangunan bersama masyarakat adalah merupakan panduan atau model pembangunan desa yang menitikberatkan pada peran serta masyarakat dalam keseluruhan proses pembangunan..

(Mustanir et al., 2018) Dalam pelaksanaan pembangunan partisipasi masyarakat sangat diharapkan dalam setiap tahapan pembangunan yang dimulai dari tahap perencanaan, tahap pelaksanaan, tahap pemanfaatan dan tahap evaluasi. Melalui pembangunan yang berbasis partisipasi masyarakat ini akan dapat dilaksanakan pembangunan daerah yang benar-benar sesuai dengan kebutuhan dan aspirasi masyarakat

Partisipasi masyarakat sangat dibutuhkan untuk membantu kegiatan seperti peningkatan mutu dan pembangunan di daerah, sesuai dengan kemampuan masing-masing. Kesediaan masyarakat untuk mengambil bagian dari penyelenggaraan suatu program pembangunan adalah merupakan indikasi adanya kemampuan awal dari masyarakat untuk menumbuhkan keberdayaan diri masyarakat dan berkembang secara mandiri. (Ahmad Mustanir 1) \& Samad 2), Abdul Jabbar 3), Monalisa Ibrahim 4), 2019) 
2. Musrenbang

Menurut (ahmad mustanir, 2017) Musrenbang adalah forum-forum multi-pihak terbuka yang secara bersama mengidentifikasi dan menentukan prioritas kebijakan pembangunan masyarakat. Musyawarah perencanaan pembangunan (musrenbang) kelurahan adalah forum musyawarah tahunan para pemangku kepentingan (stakeholders) kelurahan untuk menyepakati rencana kerja kelurahan tahun anggaran berikutnya15. Musrenbang merupakan forum perencanaan (program) yang diselenggarakan oleh lembaga publik yaitu pemerintah kelurahan bekerjasama dengan warga dan para pemangku kepentingan lainnya.

Musrenbang bermakna, akan mampu membangun kesepahaman tentang kepentingan dan kamajuan kelurahan dengan cara memotret potensi dan sumber-sumber pembangunan yang tersedia baik dari dalam maupun dari luar daerah. Musrenbang adalah Perencanaan Pembangunan Bersama Masyarakat adalah merupakan panduan atau model pembangunan kelurahan yang menitikberatkan pada peran serta masyarakat dalam keseluruhan proses pembangunan 16. Pendekatan ini dilandasi oleh nilai-nilai dan semangat gotong-royong yang telah mengakar dalam budaya masyarakat Indonesia. Gotong-royong bertumpu pada keyakinan bahwa setiap warga masyarakat memiliki hak untuk memutuskan dan merencanakan apa yang terbaik bagi diri dan lingkungan serta cara terbaik dalam upaya mewujudkannya. Secara garis besar musrenbang mengandung pengertian sebagai berikut:

1. Perencanaan sebagai serangkaian kegiatan analisis mulai dari indentifikasi kebutuhan masyarakat hingga penetapan program pembangunan.

2. Perencanaan pembangunan lingkungan, semua program peningkatan kesejahteraan, ketenteraman, kemakmuran dan perdamaian masyarakat di lingkungan pemukiman dari tingkat RT/RW, dusun dan kelurahan. 
3. Perencanaan pembangunan bertumpu pada masalah, kebutuhan, aspirasi dan sumber daya masyarakat setempat.

4. Wujud nyata peran serta masyarakat dalam perencanaan pembangunan. Musrenbang berfungsi sebagai proses negosiasi, rekonsiliasi dan harmonisasi

perbedaan antara pemerintah dan pemangku kepentingan non pemerintah, sekaligus mencapai consensus bersama mengenai prioritas kegiatan pembangunan anggaran.

Musrenbang adalah forum-forum multi-pihak terbuka yang secara bersama mengidentifikasi dan menentukan prioritas kebijakan pembangunan masyarakat. Musyawarah perencanaan pembangunan (musrenbang) kelurahan adalah forum musyawarah tahunan para pemangku kepentingan (stakeholders) kelurahan untuk menyepakati rencana kerja kelurahan tahun anggaran berikutnya. Tim Kerja Buku Panduan Penyelenggaraan Musrenbang dalam Ahmad Mustanir (2016).

3. Faktor faktor yang mempengaruhi partisipasi masyarakat

Menurut Sumardi (2010:46) dalam (Sulaeman et al., 2019) mengemukakan bahwa partisipasi adlah peran serta seseorang atau kelompok masyarakat dalam proses pembangunan baik dalam bentuk pernyataan maupun dalam bentuk kegiatan dengan memberi masukan pikiran, tenaga, waktu, keahlian, modal, dan atau materi, serta ikut memanfaatkan dan menikmati hasil-hasil pembangunan.

Slamet (2002:13), mengemukakan bahwa ada beberapa faktor yang mempengaruhi partisipasi masyarakat dalam musyawarah rencana pembangunan (musrenbang) antara lain adalah faktor sosial budaya yang mencakup; norma, nilai kepercayaan, dan sikap. Bukan sesuatu hal yang mudah untuk menerapkan partisipasi terutama pada suatu lingkungan masyarakat tertentu dikarenakan faktorfaktor tersebut. Sehingga prinsip-prinsip partisipasi harus 
memperhatikan kebersamaan, tumbuh dari bawah (bottom up) dan kepercayaan dan keterbukaan.

(Mustanir \& Razak, 2017) mengemukakan Faktor-faktor yang mempengaruhi partisipasi masyarakat dalam musrenbang antara lain adalah :

1. Faktor lingkungan fisik, mencakup; kesuburan tanah, jenis tanah, iklim, topografi dan orbitasi daerah.

2. Faktor sosial ekonomi, mencakup; jenis pekerjaan, tingkat pendapatan, tingkat pendidikan, status pemilikan rumah / lahan, jumlah tanggungan keluarga, jumlah tenaga kerja keluarga dan tingkat kesehatan.

3. Faktor sosial budaya, mencakup; norma, nilai kepercayaan, pengetahuan, sikap, status pernikahan, usia, jenis kelamin, dan simbolsimbol.

4. Faktor policy pemerintah, mencakup; sifat-sifat koordinasi kepemimpinan lembaga sosial, pendekatan untuk memonitor masyarakat dan tingkat kebebasan untuk menyatukan pendapat dan keinginan. Bukan sesuatu hal yang mudah untuk menerapkan kata partisipasi terutama pada suatu lingkungan masyarakat tertentu dikarenakan faktor-faktor tersebut.

Indikator Partisipasi Masyarakat menurut Mubyartoadalah:

a) Terlibat memikul tanggung jawab pelaksanaan pembangunan

b) Musyawarah perencanaan pembangunan

c) Pelaksana hasil perencanaan pembangunan

d) Kesediaan membayar iuran sebagai dana swadaya

e) Kesediaan masyarakat dalam menyumbang material seperti pasir, batu bata, semen.

Beberapa faktor yang mempengaruhi tingkat partisipasi masyarakat didalam pembangunan desanya dalam jurnal (Adam Latif 1, Irwan2, 2019) seperti tingkat pendidikan, pekerjaan, usia, penghasilan, komunikasi dan kepemimpinannya. Pemimpin masyarakat di desa 
merupakan orang terdepan dalam menggerakkan, menuntun dan mempengaruhi masyarakat. Pemimpin yang baik adalah pemimpin yang mengutamakan tercapainya tujuan bermasyarakat secara maksimal dengan memaksimalkan partisipasi seluruh anggota masyarakatnya

\section{METEOLOGI}

Penelitian ini menggunakan tipe kualitatif dan jenis penelitian menggunakan deskriptif karena akan memberikan gambaran keadaan dari objek penelitian sesuai dengan yang ada di lapangan partisipasi masyarakat dalam perencanaan pembangunan (Sugiyono, dalam Mustanir, Latif, et al., 2019).

Populasi dalam penelitian ini adalah sebanyak 30785 jiwa penduduk dari keseluruhan jumlah penduduk, yang berdasarkan sumber data yang ada. Dimana teknik penarikan sampel yang digunakan adalah non porobability sampling.

Teknik pengumpulan data dalam penelitian ini adalah : Observasi, dan Study Literature Review (Library Research). Pendekatan yang digunakan pada penelitian ini yaitu dengan menggunakan pendekatan literature. Dalam melakukan pengumpulan data, peneliti mengumpulkan data dan sumber informasi yang berhubungan dengan analisis kebijakan deliberatif dan perencanaan pembangunan melalui data-data pendukung yang bersumber dari jurnal penelitian yang relevab, artikel, buku-buku penunjang, surat kabar dan majalah, ulasan, rangkuman, dan pemikiran penulis tentang beberapa sumber pustaka (slide, informasi dari internet, data gambar dan grafik dan lain lain) tentang topik yang dibahas. (Hariyanti \& Wirapraja, 2018)

\section{Hasil dan Pembahasan}

Keberhasilan suatu proses pembangunan tidak dapat dilepaskan dari adanya partisipasi anggota masyrakatnya, baik sebagai kesatuan sistem maupun sebagai individu yang merupakan bagi yang sangat integral yang sangat penting dalam proses dinamika pembangunan, karena secara prinsip 
pembangunan ditunjukkan guna mewujudkan masyarakat yang sejahtera. Oleh sebab itu tanggung jawab berhasil tidaknya pembangunan tidak saja ditangan pemerintah tetapi juga ditangan masyarakat. Kesadaran dan partisipasi aktif dari masyarakat merupakan salah satu kunci keberhasilan pembangunan, dalam hal ini mencapai target pembangunan perlu ditunjukkan oleh kebijaksanaan pemerintah. Masalah Faktor-faktor Yang Mempengaruhi Partisipasi Masyarakat Dalam Perencanaan Pembangunan Desa. Yang mana disini masyarakat sebagai sobjek dan objek pembangunan harus diikut sertakan secara aktif dalam pembangunan dan menikmati hasil pembangunan serta melestarikan proses pembangunan itu sendiri secara berkesinambungan, oleh karena itu proses pembangunan secara alamiah harus muncul dari masyarakat, dilaksanakan oleh masyarakat dan dinikmati oleh masyarakat.

E. Kesimpulan

Berdasarkan hasil penelitian, faktor-faktor yang mempengaruhi partisipasi masyarakat dalam perencanaan pembangunan di Desa Sipodeceng Kecamatan Baranti Kabuaten Sidrap adalah

1) faktor kepemimpinan. Kepala Desa sudah melaksanakan konsep perencanaan partisipatif di Desa Sipodeceng. Hal ini ditunjukkan dengan Pemerintah Desa telah melakukan musyawarah dengan masyarakat dalam menetapkan programprogram pembangunan, memperhatikan aspirasi masyarakat Desa dalam merencanakan pembangunan Desa, berusaha untuk memberdayakan masyarakat sehingga masyarakat dapat mengetahui perencanaan pembangunan Desa dan masyarakat diberi kebebasan untuk mengemukakan aspirasi atau pikiran mengenai pembangunan Desa yang akan dilaksanakan.

2) Faktor komunikasi. Komunikasi tentang pembangunan Desa yang dilakukan oleh Pemerintah Desa dan BPD dengan masyarakat telah dilakukan dan bahkan selalu dilakukan komunikasi dengan masyarakat. Dari hasil penelitian juga diketahui bahwa perencanaan pembangunan yang 
oleh Kepala Desa, beserta aparatnya, masyarakat sudah tahu dengan program-program pembangunan apabila semua itu telah dilaksanakan, masyarakat juga dilibatkan secara langsung dalam pembangunan Desa tentang perencanaan pembangunan Desa yang dilakukan oleh Pemerintah Desa dengan masyarakat sangat jarang dilakukan dan bahkan tidak pernah dilakukan komunikasi dengan masyarakat.

3) Faktor pendidikan. Tingkat pendidikan masyarakat Desa Jatimulya yang rendah mempengaruhi partisipasi masyarakat dalam perencanaan pembangunan. Hal ini terbukti dengan adanya masyarakat yang tidak paham dengan proses dan perencanaan pembangunan di Desanya.

\section{Daftar Pustaka}

Adam Latif 1, Irwan2, A. M. (2019). Analisis Kepemimpinan Terhadap Optimalisasi Masyarakat Pada Perencanaan Pembangunan Di Enrekang. JAKPP, 1-20. https://doi.org/10.20956/xxxxxx

ahmad mustanir, partisan abadi. (2017). Partisipasi masyarakat dalam musyawarah rencana pembangunan di kelurahan kanyuara kecamatan watang sidenreng kabupaten sidenreng rappang. 5(2).

Ahmad Mustanir 1), Z., \& Samad 2), Abdul Jabbar 3), Monalisa Ibrahim 4), J. (2019). KEPEMIMPINAN LURAH TERHADAP PEMBERDAYAAN MASYARAKAT DI KELURAHAN LAUTANG BENTENG KABUPATEN SIDENRENG RAPPANG. 1(2), 20-39.

Ahmad Mustanir1), M., Andi Uceng3), M.Nurzin R. Kasau4), B. D. A., \& 1). (2019). karakteristik kepemimpinan LURAH TERHADAP PARTISIPASI MASYARAKAT DALAM MUSYAWARAH PERENCANAAN PEMBANGUNAN DI KELURAHAN DUAMPANUA KECAMATAN BARANTI KABUPATEN SIDENRENG RAPPANG. Jurnal Ilmiah Clean Government, 1(1), 41-57. http://www.ghbook.ir/index.php?name= فرهنى و 
نوين\&option=com_dbook\&task=readonline\&book_id=13650\&page=73\&chk hashk=ED9C9491B4\&Itemid=218\&lang=fa\&tmpl=component\%0Ahttp://w ww.albayan.ae\%0Ahttps://scholar.google.co.id/scholar?hl=en\&q=APLIKAS I+PENGENA

Hariyanti, N. T., \& Wirapraja, A. (2018). PENGARUH INFLUENCER MARKETING SEBAGAI STRATEGI PEMASARAN DIGITAL ERA MODEREN ( SEBUAH STUDI LITERATUR ). Jurnal EKSEKUTIF, 15(1), 133-146.

Mustanir, A., Fitriani, S., Adri, K., Nurnawati, A. A., \& Goso, G. (2020). Sinergitas Peran Pemerintah Desa dan Partisipasi Masyarakat Terhadap Perencanaan Pembangunan di Kabupaten Sidenreng Rappang (The Synergy of Village Government's Role and Community Participation in the Process of Development Planning in Sidenreng Rappang D. Journal of Government Science (GovSci), 2020(2), 84-108.

Mustanir, A., Kamarudding, S., Akhwan, A., Madaling, \& Mutmainna. (2018). Peranan Aparatur Pemerintahan Desa dan Partisipasi Masyarakat Dalam Musyawarah Perencanaan Pembangunan di Desa Tonrongnge Kecamatan Baranti Kabupaten Sidenreng Rappang. Jurnal Ilmiah Clean Government, 2(Desember), $67-84$. http://lonsuit.unismuhluwuk.ac.id/index.php/clean/article/view/213

Mustanir, A., Latif, A., \& Irwan, I. (2019). Analisis Kepemimpinan Terhadap Optimalisasi Masyarakat Pada Perencanaan Pembangunan Di Enrekang. Jurnal Analisis Kebijakan Dan Pelayanan Publik (JAKPP), 5(2), 1-20.

Mustanir, A., \& Razak, M. R. R. (2017). Nilai Sosial Budaya Pada Partisipasi Masyarakat Etnik Towani Tolotang Dalam Musyawarah Rencana Pembangunan. Prosiding Konferensi Nasional Ke-6 Asosiasi Program Pascasarjana Perguruan Tinggi Muhammadiyah Aisyiyah (APPPTMA), September, 1-7. http://asosiasipascaptm.or.id/index.php/publikasi/prosidingkonferensi-nasional-appptma-ke-6 
Mustanir, A., \& Yasin, A. (2018). Transect Pada Perencanaan Pembangunan Partisipatif. 8(2), 21-31.

Sulaeman, Z., Mustanir, A., \& Muchtar, A. I. (2019). Partisipasi Masyarakat Terhadap Perwujudan Good Governance Di Desa Damai Kecamatan Watang Sidenreng Kabupaten Sidenreng Rappang. PRAJA: Jurnal Ilmiah Pemerintahan, 7(3), 88-92. https://doi.org/10.51817/prj.v7i3.374 